\title{
Disposition Group Identifier
}

National Cancer Institute

\section{Source}

National Cancer Institute. Disposition Group Identifier. NCI Thesaurus. Code C83247.

A character or string that represents a disposition event group. 